\title{
A FURTHER TEST OF THE COMPETITIVE EFFECT IN SHIFT-SHARE ANALYSIS
}

\author{
Andreas Andrikopoulos, James Brox and Emanuel Carvalho*
}

\section{Introduction}

Shift-share analysis has been used to examine regional and urban development by breaking growth into three more easily understood components: (1) the national growth component, which represents growth that would have occurred in the region if all industries had grown at the national average; (2) the industrial-mix component, which measures growth that would have occurred if existing industries had grown at the same rate as those industries in the national economy, and, thus, is viewed as a measure of the effect of the existing industrial structure on regional growth; and (3) the regional share (differential or competitive) component, measured residually, which is interpreted as a measure of regional competitiveness. The usefulness of shift-share analysis, especially with respect to the regional competitive share component, has received considerable debate in the literature.'

A recent paper by Ireland and Moomaw (1981) follows a new approach by using the regional competitive share component to predict the level of capital information by a given industry in the region. Their results, while not conclusive, tend to support use of such relationships in a forecast environment, but data limitations prevented them from undertaking an out-of-sample test of the predictive performance of the model.

The purpose of this paper is to test further the hypothesis set out by Ireland and Moomaw by applying the same analysis to data for twenty two-digit industries for the provinces of Ontario and Quebec and by extending the analysis to include an out-of-sample ex post forecast evaluation.

\section{The Model}

The model by Ireland and Moomaw is designed to test the competitive share of the shift-share model as a measure of the region's competitive advantage. Following Browne, Mieszkowski and Syron (1980), and Hodge (1981), the investment in a particular industry in the region is assumed to be a function of the regional comparative advantage and the growth prospects for the industry nationally. In addition, lagged value-added is included

*Department of Economics, University of Waterloo, Waterloo, Ontario, Canada. This paper has benefitted from the comments of the anonymous referees of this journal. to proxy the need for replacement investment.

Ireland and Moomaw follow Bishop and Simpson (1972) and Esteban-Marquillas (1972) in defining the competitive component as the difference between the regional and national growth rates for the industry multiplied by the homothetic output.

The exact form of the investment model by Ireland and Moomaw is as follows:

$I_{i}=a+b Q l_{i}+c R N_{i}+d_{C O M}+$ Random Term, (1)

where $a, b, c$, and d are parameters to be estimated, $I_{i}$ is real investment in industry $\mathrm{i}_{,} \mathrm{Ql}_{\mathrm{i}}$ is lagged real output (valueadded) in industry $i, R_{i}$ is the national growth rate in real output (value-added) in industry $i$, and $\mathrm{COM}_{1}$ is the competitive effect in industry $i$ from shift-share analysis of real output (value-added).

As an alternative hypothesis, Ireland and Moomaw testa similar functional form with the industry growth rate in the region, $R_{i}$, substituted for both $R_{i}$ and $C O M_{i}$. Thus, the alternative form of the model is the following:

$$
I_{i}=f+g l_{i}+h R_{i}+\text { Random Term }
$$

where $f, g$, and $h$ are parameters to be estimated, $R_{i}$ is the regional growth rate of industry $i$, and all other variables are as previously defined.

\section{Empirical Results}

We estimated equations (1) and (2) using data for twenty two-digit industries from the provinces of Ontario and Quebec for the period 1962 to 1977. As well as looking at the in-sample results, we have tested the model's ability to predict events out of the sample by simulating the equations for the period 1978-1982. We follow the simple procedure of calculating the shift and share components for the value-added of each industry in each province. The regional competitive share is used as a proxy for the competitive share variable, COM, in equation (1).

The data on value-added by industry were obtained from Statistics Canada catalogue \#31-203 and the data on investment were obtained from the Construction Division of Statistics Canada. The estimated results for Ontario are presented in Table 1 with those for Quebec in Table 2.

The regression results in Tables 1 and 2 are quite comparable to those found by Ireland and Moomaw for 
Oklahoma. The coefficient on lagged value-added is positive in all cases and significantly different from zero in all cases, except for knitting mills in Quebec. Overall, the fit of the equations using the competitive component as a major factor explaining the amount of investment in each industry is slightly better than the naive alternative hypothesis. Although the differences tend to be quite small, the competitive share version has a higher $\mathbf{R}^{2}$ in twenty-two of the forty cases. However, the true test of whether the competitive share is an important determinant of investment decisions hinges on whether the comparative advantage term is significant in the investment equations.

The regional comparative advantage term is significantly positive at least at the ten percent level in only nine of the forty equations. ${ }^{2}$ The national growth effect is slightly more successful, with a positive coefficient found to be statistically significant in twenty-one of the forty

Table 1

Regression Results Province of Ontario

\begin{tabular}{|c|c|c|c|c|c|c|c|}
\hline Industry & Intercept & Q1 & $\mathrm{COM}$ & $\overline{\mathbf{R N}}$ & $\mathbf{R}$ & $\mathbf{R}^{2}$ & DW \\
\hline \multirow[t]{2}{*}{ Food \& Beverage } & $\begin{array}{r}-205.87 \\
(2.98)\end{array}$ & $\begin{array}{l}0.00025^{2} \\
(3.48)\end{array}$ & $\begin{array}{l}0.00036 \\
(0.49)\end{array}$ & $\begin{array}{r}1422.6^{c} \\
(1.45)\end{array}$ & & 0.802 & 1.68 \\
\hline & $\begin{array}{r}-200.81 \\
(3.21)\end{array}$ & $\begin{array}{l}0.00026^{2} \\
(6.76)\end{array}$ & & & $\begin{array}{r}1185.8^{b} \\
(1.78)\end{array}$ & 0.812 & 1.69 \\
\hline \multirow[t]{2}{*}{ Tobacco Industries } & $\begin{array}{l}-0.116 \\
(0.05)\end{array}$ & $\begin{array}{l}0.00008 \\
(3.86)\end{array}$ & $\begin{array}{l}-0.00019 \\
(1.45)\end{array}$ & $\begin{array}{l}52.79 \\
(3.84)\end{array}$ & & 0.728 & 1.54 \\
\hline & $\begin{array}{l}-0.944 \\
(0.35)\end{array}$ & $\begin{array}{l}0.00010^{\circ} \\
(4.73)\end{array}$ & & & $\begin{array}{l}16.95^{b} \\
(1.96)\end{array}$ & 0.572 & 1.67 \\
\hline Rubber \& Plastics & -27.67 & $0.00026^{2}$ & 0.00003 & 26.38 & & 0.833 & 1.74 \\
\hline \multirow[t]{2}{*}{ Products \& Industries } & $(1.78)$ & $(9.09)$ & $(0.21)$ & $(0.44)$ & & & \\
\hline & $\begin{array}{r}-24.38 \\
(1.83)\end{array}$ & $\begin{array}{l}0.00026^{2} \\
(9.36)\end{array}$ & & & $\begin{array}{c}5.40 \\
(0.14)\end{array}$ & 0.843 & 1.74 \\
\hline \multirow[t]{2}{*}{ Leather Industries } & $\begin{array}{c}-19.69 \\
(7.43)\end{array}$ & $\begin{array}{l}0.00027 \\
(10.69)\end{array}$ & $\begin{array}{l}-0.00075 \\
(2.78)\end{array}$ & $\begin{array}{l}48.79 \\
(3.54)\end{array}$ & & 0.907 & 1.56 \\
\hline & $\begin{array}{r}-15.54 \\
(5.09)\end{array}$ & $\begin{array}{l}0.00024^{\circ} \\
(7.96)\end{array}$ & & & $\begin{array}{l}19.54^{c} \\
(1.42)\end{array}$ & 0.839 & 1.55 \\
\hline \multirow[t]{2}{*}{ Textile Industries } & $\begin{array}{c}-27.29 \\
(1.38)\end{array}$ & $\begin{array}{l}0.00037 \\
(7.53)\end{array}$ & $\begin{array}{l}-0.00026 \\
(0.73)\end{array}$ & $\begin{array}{r}-153.10 \\
(1.33)\end{array}$ & & 0.777 & 1.49 \\
\hline & $\begin{array}{l}-27.20 \\
(1.41)\end{array}$ & $\begin{array}{l}0.00035^{2} \\
(7.67)\end{array}$ & & & $\begin{array}{r}-135.93 \\
(1.64)\end{array}$ & 0.788 & 1.53 \\
\hline \multirow[t]{2}{*}{ Knitting Mills } & $\begin{array}{l}-2.55 \\
(0.42)\end{array}$ & $\begin{array}{l}0.00010 \\
(1.06)\end{array}$ & $\begin{array}{l}0.00024 \\
(0.92)\end{array}$ & $\begin{array}{c}8.25 \\
(0.92)\end{array}$ & & 0.172 & 1.03 \\
\hline & $\begin{array}{l}-4.96 \\
(1.19)\end{array}$ & $\begin{array}{l}0.00014^{b} \\
(1.91)\end{array}$ & & & $\begin{array}{l}12.89 \\
(0.83)\end{array}$ & 0.210 & 0.87 \\
\hline \multirow[t]{2}{*}{ Clothing Industries } & $\begin{array}{l}-6.42 \\
(1.91)\end{array}$ & $\begin{array}{l}0.00005 \\
(2.42)\end{array}$ & $\begin{array}{l}0.00005 \\
(0.42)\end{array}$ & $\begin{array}{l}23.43 \\
(0.84)\end{array}$ & & 0.506 & 1.29 \\
\hline & $\begin{array}{l}-6.36 \\
(2.38)\end{array}$ & $\begin{array}{l}0.00005^{2} \\
(2.81)\end{array}$ & & & $\begin{array}{l}23.11 \\
(1.01)\end{array}$ & 0.547 & 1.29 \\
\hline \multirow[t]{2}{*}{ Wood Industries } & $\begin{array}{c}-21.31 \\
(3.06)\end{array}$ & $\begin{array}{l}0.00037^{\circ} \\
(12.08)\end{array}$ & $\begin{array}{l}-0.00004 \\
(1.28)\end{array}$ & $\begin{array}{c}-49.54 \\
(2.02)\end{array}$ & & 0.900 & 0.90 \\
\hline & $\begin{array}{c}-22.31 \\
(3.29)\end{array}$ & $\begin{array}{l}0.00037^{\circ} \\
(12.27)\end{array}$ & & & $\begin{array}{c}-53.79 \\
(2.05)\end{array}$ & 0.903 & 0.88 \\
\hline \multirow[t]{2}{*}{$\begin{array}{l}\text { Fumiture \& Fixture } \\
\text { Industries }\end{array}$} & $\begin{array}{c}-12.44 \\
(3.40)\end{array}$ & $\begin{array}{l}0.00011^{2} \\
(9.00)\end{array}$ & $\begin{array}{l}-0.00108 \\
(3.64)\end{array}$ & $\begin{array}{l}50.46^{2} \\
(2.56)\end{array}$ & & 0.841 & 1.90 \\
\hline & $\begin{array}{l}-8.10 \\
(1.65)\end{array}$ & $\begin{array}{l}0.00011^{2} \\
(6.03)\end{array}$ & & & $\begin{array}{l}13.36 \\
(0.57)\end{array}$ & 0.683 & 1.47 \\
\hline
\end{tabular}




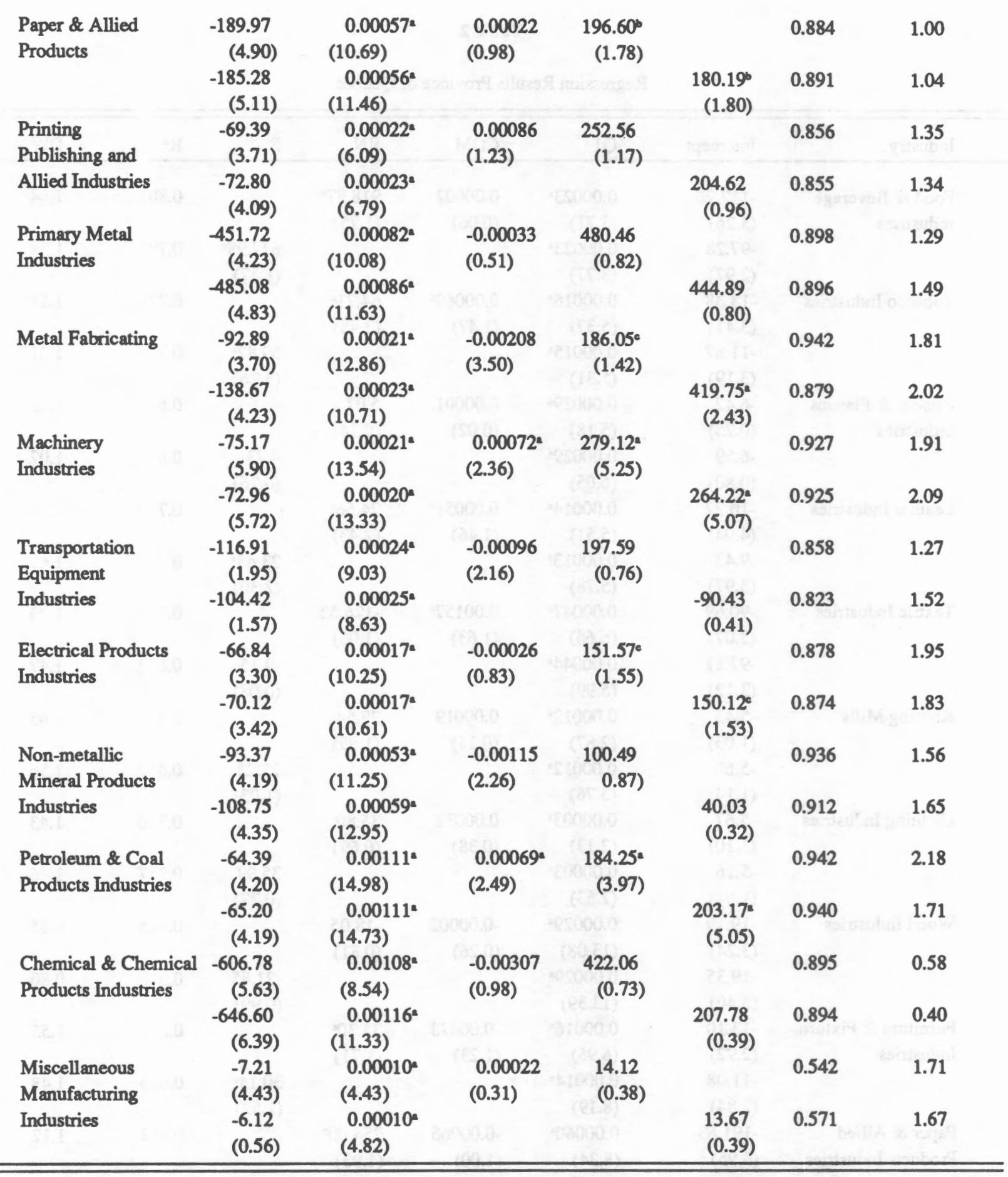

-Denotes significance at 0.10 level.

'Denotes significance at 0.05 level.

'Denotes significance at 0.025 level. 
Table 2

Regression Results Province of Quebec

\begin{tabular}{|c|c|c|c|c|c|c|c|}
\hline Industry & Intercept & Q1 & COM & $\mathbf{R N}$ & $\mathbf{R}$ & $\mathbf{R}^{2}$ & DW \\
\hline \multirow{4}{*}{$\begin{array}{l}\text { Food \& Beverage } \\
\text { Industries }\end{array}$} & -117.26 & $0.00023^{2}$ & 0.00002 & $918.87^{\circ}$ & & 0.803 & 1.64 \\
\hline & $(3.26)$ & $(3.77)$ & $(0.06)$ & $(1.75)$ & & & \\
\hline & -97.28 & $0.00023^{2}$ & & & $677.98^{\circ}$ & 0.797 & 1.58 \\
\hline & (2.97) & $(3.77)$ & & & $(1.37)$ & & \\
\hline \multirow[t]{4}{*}{ Tobacco Industries } & -13.38 & $0.00016^{a}$ & $0.00060^{\circ}$ & $64.71^{2}$ & & 0.770 & 1.58 \\
\hline & $(3.41)$ & $(5.37)$ & $(1.47)$ & $(3.48)$ & & & \\
\hline & -11.87 & $0.00015^{2}$ & & & $59.82^{2}$ & 0.765 & 1.31 \\
\hline & (3.19) & $(5.31)$ & & & $(3.26)$ & & \\
\hline \multirow{4}{*}{$\begin{array}{l}\text { Rubber \& Plastics } \\
\text { Industries }\end{array}$} & -6.42 & 0.00029 & 0.00001 & 5.07 & & 0.663 & 1.02 \\
\hline & $(0.75)$ & $(5.18)$ & $(0.02)$ & $(0.14)$ & & & \\
\hline & -6.59 & 0.00029 & & & 4.73 & 0.688 & 1.02 \\
\hline & $(0.80)$ & $(6.05)$ & & & $(0.26)$ & & \\
\hline \multirow[t]{4}{*}{ Leather Industries } & -10.27 & $0.00014^{a}$ & $0.00051^{c}$ & $24.66^{a}$ & & 0.727 & 1.26 \\
\hline & $(4.04)$ & $(5.51)$ & $(1.46)$ & $(2.43)$ & & & \\
\hline & -9.43 & $0.00013^{2}$ & & & $23.48^{2}$ & 0.724 & 1.49 \\
\hline & $(3.97)$ & (5.78) & & & $(2.30)$ & & \\
\hline \multirow[t]{4}{*}{ Textile Industries } & -90.69 & 0.00047 & $0.00157^{c}$ & -126.53 & & 0.729 & 1.73 \\
\hline & $(3.07)$ & $(6.66)$ & (1.63) & $(1.05)$ & & & \\
\hline & -97.11 & $0.00044^{*}$ & & & -9.15 & 0.682 & 1.47 \\
\hline & $(3.12)$ & $(5.99)$ & & & $(0.08)$ & & \\
\hline \multirow[t]{4}{*}{ Knitting Mills } & -5.43 & $0.00012^{2}$ & 0.00019 & 29.54 & & 0.404 & 1.65 \\
\hline & $(1.03)$ & $(2.87)$ & $(0.14)$ & $(1.05)$ & & & \\
\hline & -5.60 & $0.00012^{a}$ & & & 23.23 & 0.432 & 1.56 \\
\hline & (1.14) & $(3.76)$ & & & $(1.03)$ & & \\
\hline \multirow[t]{4}{*}{ Clothing Industries } & -5.67 & $0.00003^{2}$ & 0.00032 & 35.80 & & 0.330 & 1.43 \\
\hline & $(1.10)$ & (2.13) & $(0.38)$ & $(0.69)$ & & & \\
\hline & -5.16 & $0.00003^{2}$ & & & 35.99 & 0.367 & 1.46 \\
\hline & (1.07) & $(2.53)$ & & & $(0.77)$ & & \\
\hline \multirow[t]{4}{*}{ Wood Industries } & -19.19 & 0.00029 & -0.00002 & -18.05 & & 0.915 & 0.85 \\
\hline & $(3.24)$ & $(13.08)$ & $(0.26)$ & $(0.81)$ & & & \\
\hline & -19.35 & 0.00029 & & & -21.85 & 0.919 & 0.80 \\
\hline & $(3.40)$ & (13.39) & & & $(0.99)$ & & \\
\hline \multirow{4}{*}{$\begin{array}{l}\text { Furniture \& Fixture } \\
\text { Industries }\end{array}$} & -13.10 & $0.00016^{a}$ & -0.00073 & $35.30^{\circ}$ & & 0.801 & 1.55 \\
\hline & (2.92) & $(6.96)$ & $(1.23)$ & (1.71) & & & \\
\hline & -11.08 & $0.00014^{2}$ & & & $30.14^{c}$ & 0.803 & 1.48 \\
\hline & $(2.84)$ & $(8.19)$ & & & $(1.52)$ & & \\
\hline \multirow{4}{*}{$\begin{array}{l}\text { Paper \& Allied } \\
\text { Products Industries }\end{array}$} & -191.63 & $0.00060^{2}$ & -0.00065 & $254.00^{\circ}$ & & 0.867 & 1.12 \\
\hline & (3.95) & (8.34) & $(1.00)$ & $(1.93)$ & & & \\
\hline & -154.02 & $0.00053^{2}$ & & & $344.36^{2}$ & 0.860 & 0.79 \\
\hline & (3.57) & $(9.09)$ & & & $(2.73)$ & & \\
\hline \multirow{4}{*}{$\begin{array}{l}\text { Printing } \\
\text { Publishing and } \\
\text { Allied Industries }\end{array}$} & -27.26 & $0.00015^{a}$ & -0.00034 & $172.53^{b}$ & & 0.856 & 1.50 \\
\hline & $(3.56)$ & $(5.60)$ & $(1.33)$ & $(1.80)$ & & & \\
\hline & -22.90 & 0.00018 & & & 22.78 & 0.835 & 1.42 \\
\hline & $(3.02)$ & $(8.62)$ & & & $(0.47)$ & & \\
\hline \multirow{2}{*}{$\begin{array}{l}\text { Primary Metal } \\
\text { Industries }\end{array}$} & -190.01 & 0.00078 & -0.00003 & 377.98 & & 0.810 & 1.30 \\
\hline & $(3.33)$ & $(7.28)$ & $(0.11)$ & $(1.19)$ & & & \\
\hline
\end{tabular}




\begin{tabular}{|c|c|c|c|c|c|c|c|}
\hline & $\begin{array}{l}-166.82 \\
(3.71)\end{array}$ & $\begin{array}{l}0.00078 \\
(7.80)\end{array}$ & & & $\begin{array}{l}152.47^{\mathrm{e}} \\
(1.37)\end{array}$ & 0.820 & 1.02 \\
\hline Metal Fabricating & -53.24 & $0.00020^{\circ}$ & $0.00032^{b}$ & $161.71^{\circ}$ & & 0.915 & 2.13 \\
\hline \multirow{2}{*}{ Industries } & $(5.82)$ & $(12.72)$ & $(1.95)$ & $(3.58)$ & & & \\
\hline & $\begin{array}{l}-50.27 \\
(5.51)\end{array}$ & $\begin{array}{l}0.00017^{2} \\
(11.84)\end{array}$ & & & $\begin{array}{l}150.35^{a} \\
(3.51)\end{array}$ & 0.905 & 2.06 \\
\hline Machinery & -14.54 & $0.00018^{a}$ & 0.00005 & $46.43^{\circ}$ & & 0.937 & 1.78 \\
\hline \multirow[t]{2}{*}{ Industries } & $(5.44)$ & $(14.68)$ & $(1.14)$ & $(3.80)$ & & & \\
\hline & $\begin{array}{l}-12.10 \\
(4.24)\end{array}$ & $\begin{array}{l}0.00018^{2} \\
(12.86)\end{array}$ & & & $\begin{array}{l}28.26^{2} \\
(2.86)\end{array}$ & 0.916 & 1.55 \\
\hline $\begin{array}{l}\text { Transportation } \\
\text { Equipment }\end{array}$ & $\begin{array}{l}-23.20 \\
(1.10)\end{array}$ & $\begin{array}{l}0.00021^{a} \\
(4.46)\end{array}$ & $\begin{array}{l}0.00015= \\
(2.95)\end{array}$ & $\begin{array}{l}65.01 \\
(0.93)\end{array}$ & & 0.662 & 0.68 \\
\hline Industries & $\begin{array}{l}-32.99 \\
(1.92)\end{array}$ & $\begin{array}{l}0.00022^{4} \\
(4.95)\end{array}$ & & & $\begin{array}{l}138.59^{\circ} \\
(3.20)\end{array}$ & 0.693 & 0.78 \\
\hline \multirow[t]{2}{*}{$\begin{array}{l}\text { Electrical Products } \\
\text { Industries }\end{array}$} & $\begin{array}{l}-33.44 \\
(3.58)\end{array}$ & $\begin{array}{l}0.00019 \\
(9.98)\end{array}$ & $\begin{array}{l}0.00024^{4} \\
(2.45)\end{array}$ & $\begin{array}{l}125.30^{\circ} \\
(2.80)\end{array}$ & & 0.872 & 2.08 \\
\hline & $\begin{array}{l}-28.77 \\
(3.08)\end{array}$ & $\begin{array}{l}0.00019^{a} \\
(9.00)\end{array}$ & & & $\begin{array}{l}78.98^{\mathrm{a}} \\
(2.52)\end{array}$ & 0.838 & 1.85 \\
\hline $\begin{array}{l}\text { Non-metallic } \\
\text { Mineral Products }\end{array}$ & $\begin{array}{l}-58.11 \\
(4.43)\end{array}$ & $\begin{array}{l}0.00049 \\
(9.58)\end{array}$ & $\begin{array}{l}0.00068 \\
(2.33)\end{array}$ & $\begin{array}{l}105.56^{\mathrm{c}} \\
(1.50)\end{array}$ & & 0.861 & 1.43 \\
\hline Industries & $\begin{array}{l}-54.90 \\
(4.37)\end{array}$ & $\begin{array}{l}0.00045^{2} \\
(9.65)\end{array}$ & & & $\begin{array}{l}134.86^{\circ} \\
(2.57)\end{array}$ & 0.857 & 1.80 \\
\hline \multirow[t]{2}{*}{ Product Industries } & $\begin{array}{l}-1.36 \\
(0.09)\end{array}$ & $\begin{array}{l}0.00061^{\circ} \\
(6.40)\end{array}$ & $\begin{array}{l}0.00036 \\
(0.84)\end{array}$ & $\begin{array}{l}125.137 \\
(1.67)\end{array}$ & & 0.793 & 1.07 \\
\hline & $\begin{array}{l}-0.93 \\
(0.06)\end{array}$ & $\begin{array}{l}0.00061^{\circ} \\
(7.52)\end{array}$ & & & $\begin{array}{l}107.24^{\circ} \\
(3.89)\end{array}$ & 0.801 & 1.19 \\
\hline $\begin{array}{l}\text { Chemical \& Chemical } \\
\text { Products Industries }\end{array}$ & $\begin{array}{l}-159.41 \\
(4.41)\end{array}$ & $\begin{array}{l}0.00064^{a} \\
(8.36)\end{array}$ & $\begin{array}{l}-0.00005 \\
(0.05)\end{array}$ & $\begin{array}{l}231.02 \\
(1.03)\end{array}$ & & 0.845 & 1.37 \\
\hline Products Industries & $\begin{array}{l}-159.54 \\
(4.71)\end{array}$ & $\begin{array}{l}0.00066^{\circ} \\
(9.01)\end{array}$ & & & $\begin{array}{l}178.01 \\
(0.97)\end{array}$ & 0.849 & 1.29 \\
\hline Miscellaneous & -10.79 & $0.00011^{\prime}$ & 0.00012 & 19.09 & & 0.838 & 1.09 \\
\hline Manufacturing & $(4.31)$ & $(8.44)$ & $(1.34)$ & $(2.49)$ & & & \\
\hline Industries & $\begin{array}{l}-11.24 \\
(4.91)\end{array}$ & $\begin{array}{l}0.00011^{2} \\
(9.15)\end{array}$ & & & $\begin{array}{l}21.20^{4} \\
(3.07)\end{array}$ & 0.849 & 1.13 \\
\hline
\end{tabular}

-Denotes signifcance at 0.10 level.

'Denotes significance at 0.05 level.

'Denotes significance at 0.025 level.

cases. ${ }^{3}$ On the other hand, the naive alternative, using the actual growth in the industry in the region, was found to be statistically positive in twenty-one of the cases. Thus, we conclude that using the competitive share component as a measure of regional comparative advantage is not vastly superior to the naive alternative of simply using industrial growth in the region as the main determinant of investment. ${ }^{4}$

In order to test more effectively the ability of the regional comparative advantage variable to forecast the future levels of investment in each industry, Ireland and Moomaw simulated the models and calculated various test statistics to measure the predictive powers of the two versions of the model. All such tests, limited by data to be performed in the estimation period, showed that in over two-thirds of the industries studied, the version of the model with the regional comparative advantage and the national growth effects entered separately outperformed the naive alternative model.

In this paper, we have followed a similar process and extended the analysis to include an ex post forecast evaluation of the two versions of the model. The results of these simulations are summarized in Table 3.

Our simulation results for the in-sample period again confirm those for Oklahoma by Ireland and Moomaw. The Theil's U statistics calculated from the insample simulations reveal that the regional share version of the model outperforms the naive version in all but four 
of the forty cases. In addition, the simple average of the Theil's U statistics for Ontario is 0.630 for the regional share version, as compared to 0.692 for the naive version, and for Quebec the comparable values are 0.712 and 0.743 respectively. However, the ex post simulations fail to support the use of the regional share version of the model. The Theil's $U$ statistics for the out-of-sample simulations support the use of the naive alternative hypothesis in twenty-nine of the forty cases. Moreover, in twenty of the forty cases, the Theil's U statistic is greater than the critical value of unity for the model containing the regional share and national growth components. ${ }^{5}$ Therefore, we conclude that the competitive effect in shift-share analysis is not particularly useful in predicting regional investment patterns.

Table 3

Predictive Performance of the Models

\begin{tabular}{|c|c|c|c|c|}
\hline \multirow[t]{2}{*}{ Industry } & \multicolumn{2}{|l|}{$\begin{array}{l}\text { Theil's U } \\
\text { in sample }\end{array}$} & \multicolumn{2}{|l|}{$\begin{array}{l}\text { Theil's U } \\
\text { ex post }\end{array}$} \\
\hline & COM & $\mathbf{R}$ & COM & $\mathbf{R}$ \\
\hline \multicolumn{5}{|l|}{ Ontario } \\
\hline Food \& Beverage & 0.690 & 0.699 & 0.979 & 0.887 \\
\hline Tobacco & 0.574 & 0.737 & 1.376 & 1.311 \\
\hline Rubber \& Plastics & 0.660 & 0.665 & 1.195 & 1.292 \\
\hline Leather & 0.529 & 0.751 & 1.643 & 0.868 \\
\hline Textile & 0.586 & 0.593 & 2.383 & 1.149 \\
\hline Knitting Mills & 1.012 & 1.015 & 0.747 & 0.684 \\
\hline Clothing & 0.888 & 0.880 & 0.678 & 0.577 \\
\hline Wood & 0.571 & 0.591 & 1.626 & 1.743 \\
\hline Furniture & 0.571 & 0.760 & 0.658 & 0.447 \\
\hline Paper & 0.742 & 0.746 & 0.427 & 0.418 \\
\hline Printing & 0.646 & 0.672 & 1.186 & 1.832 \\
\hline Primary Metals & 0.565 & 0.590 & 1.068 & 0.588 \\
\hline Metal Fabricating & 0.387 & 0.580 & 0.933 & 0.714 \\
\hline Machinery & 0.478 & 0.501 & 0.525 & 0.751 \\
\hline Transportation & 0.530 & 0.611 & 1.803 & 1.719 \\
\hline Electrical Products & 0.575 & 0.607 & 0.916 & 0.791 \\
\hline Non-metallic & 0.510 & 0.615 & 1.028 & 0.882 \\
\hline Petroleum \& Coal & 0.594 & 0.626 & 3.919 & 1.890 \\
\hline Chemical Products & 0.822 & 0.860 & 2.926 & 3.160 \\
\hline Miscellaneous & 0.737 & 0.739 & 0.509 & 0.433 \\
\hline Simple Average & 0.630 & 0.692 & 1.326 & 1.069 \\
\hline \multicolumn{5}{|l|}{ Quebec } \\
\hline Food \& Beverage & 0.738 & 0.776 & 1.244 & 1.369 \\
\hline Tobacco & 0.594 & 0.618 & 0.469 & 0.323 \\
\hline Rubber \& Plastics & 0.978 & 0.977 & 2.484 & 2.508 \\
\hline Leather & 0.788 & 0.821 & 1.211 & 1.043 \\
\hline Textile & 0.540 & 0.622 & 2.903 & 0.879 \\
\hline Knitting Mills & 0.765 & 0.776 & 0.992 & 0.970 \\
\hline Clothing & 0.835 & 0.843 & 0.938 & 0.818 \\
\hline Wood & 0.683 & 0.689 & 1.575 & 1.627 \\
\hline Furniture & 0.694 & 0.717 & 0.764 & 0.165 \\
\hline
\end{tabular}




\begin{tabular}{lllll} 
Paper & 0.693 & 0.734 & 0.879 & 0.414 \\
Printing & 0.643 & 0.728 & 1.161 & 1.419 \\
Primary Metals & 0.903 & 0.916 & 1.729 & 1.510 \\
Metal Fabricating & 0.511 & 0.559 & 0.597 & 0.499 \\
Machinery & 0.516 & 0.596 & 0.320 & 0.396 \\
Transportation & 0.843 & 0.835 & 1.049 & 0.563 \\
Electrical Products & 0.549 & 0.655 & 0.560 & 0.433 \\
Non-metallic & 0.627 & 0.661 & 1.543 & 1.410 \\
Petroleum \& Coal & 0.885 & 0.889 & 0.251 & 0.329 \\
Chemical Products & 0.667 & 0.677 & 0.966 & 0.941 \\
Miscellaneous & 0.782 & 0.781 & 0.716 & 0.577 \\
& & & & \\
Simple Average & 0.712 & 0.743 & 1.118 & 0.909 \\
\hline
\end{tabular}

\section{Summary and Conclusion}

In this paper, using data for the provinces of Ontario and Quebec, we have tested the Ireland and Moomaw hypothesis that the regional share component of the shiftshare model may be used as an important explanatory variable for predicting future investment decisions. Most of our results are quite comparable to those originally presented by Ireland and Moomaw. The estimation results and the in-sample predictive power tend marginally to support the use of this variable.

However, the results from the ex post forecasts yield the opposite conclusion. The results for both Ontario and Quebec fail to show any systematic support for the use of the regional competitive share component in models of industrial investment behaviour.

\section{NOTES}

'Brown (1969), Houston (1967), and Richardson (1978) are highly critical of the process. Ashby (1968), Dunn (1980), Danson, Lever and Malcolm (1980), and Fothergill and Gudgin (1979) have all shown useful applications of it. Brown (1969) claimed that the competitive share is not stable enough to allow for prediction and is too broadly defined for useful analysis. Paraskevopoulos (1971), Floyd and Sirmans (1973), and James and Hughes (1973) found shift-share projection models to be superior to naive alternative models. Although Brown (1971 and 1973) attempted to refute these claims of stability, Chalmers and Beckhelm (1976) and Andrikopoulos (1977) used formal regression analysis to show that the regional share component can be explained effectively by standard economic variables such as wages and capital formation.

2Ireland and Moomaw found a significantly positive result in six of twelve cases for this variable.

${ }^{3}$ This variable was significantly positive in six of twelve cases in Ireland and Moomaw.
${ }^{4}$ Again this finding is consistent with Ireland and Moomaw who conclude, "Thus, this variable performs somewhat better than the two variables it replaces in terms of significance levels," p. 79.

The Theil's U statistic is the ratio of the root mean squared forecast error to the root mean actual change in the data series. Thus, a model with a U statistic greater than unity is performing worse than the naive no-change forecast and is not considered to be useful for prediction.

\section{REFERENCES}

Ashby, L. D. "The Shift and Share Analysis: A Reply." Southern Economic Journal. 34 (1968). 423-25.

Andrikopoulos, A. A. "Regional Growth Differential in Manufacturing Employment: The Case of the Province of Ontario, Canada." The Review of Regional Studies. 7 (1977). 45-61.

Bishop, K. C. and C. E. Simpson. "Components of Change Analysis: Problems of Alternative Approaches to Industrial Structure." Regional Studies. 6 (1972). 59-68.

Brown, H. J. "Shift and Share Projections and Regional Economic Growth: An Empirical Test." Journal of Regional Science. (1969). 1-18.

Brown, H. J. "The Stability of the Regional Share Component: Reply." Journal of Regional Science. 11 (1971). 113-114.

Brown, H. J. "Shift and Share Projections Revisited: A Reply." Journal of Regional Science. 13 (1973). 121.

Browne, L., P. Mieszkowski and R. Syron. "Regional Investment Patterns." New England Economic Review. (July-August 1980). 5-23.

Chalmers, J. A. and T. L. Beckhelm. "Shift and Share and the Theory of Industrial Location." Regional Studies. 10 (1976). 15-23. 
Danson, M. W., W. F. Lever and J. F. Malcolm. "The Inner City Employment Problem in Great Britain, 1952 to 1976: A Shift-Share Approach." Urban Studies. 17 (1980). 193-210.

Dunn, E. S., Jr. The Development of the U.S. Urban System: Concepts, Structures, Regional Shifts. Vol. I. Baltimore: Johns Hopkins University Press, 1980.

Esteban-Marquillas, J. M. "A Reinterpretation of Shift-Share Analysis." Regional and Urban Economics. 2, 3 (1972). 249-261.

Floyd, C. F. and C. F. Sirmans. "Shift and Share Projections Revisited." Journal of Regional Science. 13 (1973). 115-120.

Fothergill, S. and G. Gudgin. "In Defense of Shift-Share." Urban Studies. 16 (1979). 303-319.

Herzog, H. W., Jr. and R. J. Olsen. "Shift-Share Analysis Revisited: The Allocation Effect and the Stability of Regional Structure, A Reply." Journal of Regional Science. 19 (1979). 393-395.

Hodge, J. H. "A Study of Regional Investment Decisions." In J. V. Henderson (ed.). Research in Urban Economics. Vol. 1. Greenwich, Conn.: JAI Press Inc., 1981. 1-66.
Houston, D. "Shift and Share Analysis: A Critique." Southern Economic Journal. 33 (1967). 577-581.

Ireland, T. C. and R. L. Moomaw. "The Competitive Effect in Shift Share Analysis: A Will Of The Wisp?" The Review of Regional Studies. 11 (1981). 72-82.

James, F., Jr. and J. Hughes. "A Test of Shift and Share Analysis as a Predictive Device." Journal of Regional Science. 13 (1973). 223-231.

Paraskevopoulos, C. C. "The Stability of the Regional-Share Component: An Empirical Test." Journal of Regional Science. 11 (1971). 107-112.

Pindyck, R. S. and D. L. Rubinfeld. Econometric Models and Economic Forecasts. New York: McGraw-Hill. 1976.

Rees, J. "Regional Industrial Shifts in the U.S. and the Internal Generation of Manufacturing in Growth Centers of the Southwest." Interregional Movements and Regional Growth. In W. C. Wheaton (ed.). Washington: The Urban Institute, 1979. 51-74.

Richardson, H. W. Urban and Regional Economics. Hamondworth: Penguin, 1978.

Stokes, H. K., Jr. "Shift-Share Once Again." Regional and Urban Economics. 4 (1974). 57-60.

Theil, H. Applied Economic Forecasting. Chicago: Rand McNally and Co., 1966. 